\title{
The Next Generation of Germiçidal Cleaners.
}

- Éffective in 5\% Blood Serum

- Broad Spectrum Germicidal Action

- Hard Water Effective

- Exceptional Cleaning Ability

\section{Quality products to meet your need for a spotless environment -today and tomorrow.}

For more information visit our Booth \#624 at the APIC ' 87 conivention. 
